Between Courts and Legislatures, International Perspectives on PolicyMaking, Religion in the 1992 Election, Religion in Middle East Politics: Behavioral Perspectives, Symbolic Politics, and Corporate Powers in American Politics.

Panels predominantly female included Feminist Identity and Social Movements, Feminist Perspectives on Hannah Arendt, Feminism, Identity and Institutions, Roundtable on Identity Politics and Coalition Building, Women in Legislative Politics, Cross-National Perspectives on Citizenship and Democratic Values, Responding to Court Decisions: Implementation? Compliance?, Representation on the Abortion Issue in Legal Systems, Fundamental Issues in Legislative Politics: Comparative Legislative Recruitment, Fairness and Equity in Administration: Race and Ethnic Categories, Sexual Harassment and Glass Ceilings, Feminist Movement or Women's Movements? The CrossNational Comparison of Activism, Markets, States and Mass Attitudes, National Identity and Political Change, Sexual Identity, Sexual Politics: Theory and Practice in the Problematic of Alliance-Building, Information Processing and Foreign Policy Analysis, as well as all the panels in the Women and Politics section.

\section{APSA Organized Sections Distribute Awards at Annual Meeting}

Nineteen of the thirty-two APSA Organized Sections used the 1993 Annual Meeting as an opportunity to recognize distinctive scholarship and career service within their fields of political science.

\section{Comparative Politics}

Award for the best work published in comparative politics during 1990 , 1991 , and 1992 was jointly awarded to Ruth Berins Collier and David Collier for "Shaping the Political Arena" (Princeton University Press, 1991), and Gregory M. Luebbert (deceased) for "Liberalism, Fascism or Social Democracy" (Oxford University Press, 1991).

\section{History and Politics}

The J. David Greenstone Best Book Award in history and politics in the past two calendar years was given as a joint award to Karen Orren, University of California-Los Angeles, Belated Feudalism: Labor, the Law, and Liberal Development in the United States (New York: Cambridge University Press, 1991), and Theda Skocpol, Harvard University, Protecting Soldiers and Mothers: The Political Origins of Social Policy in the United States (Cambridge, MA: The Belknap Press of Harvard University Press, 1992). In the citation for this award, Section President Ira Katznelson said: "Belated Feudalism is a magisterial work of historical scholarship allied to a revelatory complex of theoretical insights. The central argument, that America is not simply or unambiguously a liberal nation (and that this is revealed most clearly in laws related to labor rather than property) is sustained with devastating effect. This book contends with Hartz at his own level, with an erudition and theoretical acuity equal to his. By refuting Hartz's contention that America was born free of the presence of a feudal past, Orren forces us to reconsider the premises of the most fundamental works in American politics. It is altogether fitting that this award, which carries David Greenstone's name, should be given to a work that speaks so profoundly to the central concerns of his intellectual life.

"Protecting Soldiers and Mothers is a stunning scholarly odyssey examining how politics created and limited the United States' first major wave of social welfare policies: the provision of benefits for Union Civil War veterans; federal and state provision for mothers, potential mothers, and children; and the failure to provide, in European fashion, for working men and the elderly. These policies resulted from specific interactions between and among government institutions, prior policies, party politics, and social groups-most notably women and women's organizations. The book's synthesis of new and intriguing evidence, its strong analytic leverage provided by the use of comparative methods, and its account of long neglected history of the political contributions of Ameri- can women before they received attention as voters, make it a pathbreaking work in the study of history and politics."

\section{Federalism and}

Intergovernmental Relations

\section{A Distinguished Scholar Award} for outstanding contribution to the study of federalism and intergovernmental relations was given to Martha Derthick, University of Virginia, Charlottesville.

\section{Political Economy}

The Political Economy Best Dissertation Award was given for the best dissertation written in the past two years in any area of political economy. This award was given to Arun Agrawal, Duke University, "Risks, Resources and Politics: Studies of Institution and Resource Use from Village India."

The award for Best Published Work in 1990, 1991 and 1992 was given to Dennis Chong, Northwestern University, Collective Action and the Civil Rights Movement (Chicago: University of Chicago, 1991).

\section{Conflict Processes}

The Lifetime Achievement Award for distinguished and lasting contributions to the study of conflict was given to Robert C. North, Stanford University.

\section{Legislative Studies}

The CQ Press Award for the outstanding paper on legislative politics presented at the year's preceding APSA anual meeting was given to Liz Gerber, California Institute of Technology. In her award winning paper, Gerber compares policy outcomes resulting from the legislative process and the direct ballot process to estimate the effect of political institutions on preference aggregation and policy outcomes. Using data from California statewide elections, she analyzes policies which were considered in both processes and for which the two processes led to different outcomes. Gerber concludes that features of the legislatures, especially party, may lead legislators to vote against their district majority preference, and therefore lead legislative and direct ballot outcomes to 
diverse. In her comments anouncing the 1993 CQ Press Award, committee chair Barbara Sinclair reported: "In her paper, Gerber looks at two alternative institutional arrangements to aggregating citizen preferences in democratic governments and asks: 'Do legislative institutions lead to difference outcomes than direct ballot initiative?' Of course, the rules and procedures that define each process shape the way preferences are translated into outcomes, but are there systematic differences in the policies the two processes produce and can these differences be attributed to differences in institutional arrangements? By examining California ballot measures on which the legislatures also voted, she is able to compare outcomes from the two processes while holding issue content and political context relatively constant and thus isolate the effects of institutions. Her findings indicated that legislative institutions, most notably party, move representation away from what we would expect in a pure delegate model.

"Gerber, thus, asks a question that is of fundamental importance from the perspective both of current positive theories of legislatures and of normative democratic theory; her research design and methodology are clever and appropriate; the paper is very well written; and her findings are interesting and convincing."

The Richard F. Fenno, Jr. Prize for the outstanding book published during the preceding year in legislative studies, including American, non-American, cross-national and sub-national works, was given to Frank Sorauf, University of Minnesota, Inside Campaign Finance (New Haven: Yale University Press, 1992). Speaking on behalf of the Fenno Prize Committee at the LSS Awards Ceremony, Keith Krehbiel reported: "Published during a year in which change-if not reform-was in the winds, Inside Campaign Finance has several distinctive and admirable features. The book is a happy reminder that not all of us are fixated on abstract issues that tend to be remote from real politics. Inside Campaign Finance addresses a topic of immediate importance. But the book is not a polemic or manual for reform. Instead, Sorauf provides a compelling reminder that a prerequisite for thoughtful change is for reformers to have an awareness of myths as well as realities surrounding the system whose reform they contemplate. Inside Campaign Finance is remarkably lucid in assessing what we do and do not know. Finally and perhaps most importantly, the book meets the highest standards of scholarship. It is exhaustively researched, uniquely balanced, rich in facts, and extremely well-written."

\section{Public Administration}

The Herbert Kaufman Award for best paper in public administration presented at the APSA Annual Meeting was a joint award given to Daniel P. Carpenter, University of Chicago, and Irene S. Rubin, Northern Illinois University.

\section{State Politics and Policy}

Robert Brown, University of Mississippi, received the Best Paper Award for the best paper on state politics and policy presented at the 1992 APSA Annual Meeting.

\section{Women and Politics}

The Best Paper Awards in the fields of American and comparative politics was given as a joint award in American politics to Paul Burstein, R. Marie Bricher and Rachel L. Einwohner, University of Washington, Seattle, "Paid Work, Family and the State: Congressional Proposals to Regulate the Relationship Between Home and Work, 1945-1990"; and in the field of comparative politics an award was given to Aili Mari Tripp, University of Wisconsin-Madison, "Gender, Political Participation, and the Transformation of Associational Life in Uganda and Tanzania."

The Best Dissertation Award was given to Beth A. Reingold, Emory University, "Representing Women: Gender Difference Among Arizona and California State Legislators" (University of California at Berkeley).

\section{Caucus for a New Political Science}

The Christian Bay Award for the best paper delivered at a Caucus panel the previous year was given to Carl Boggs, National University.
Mark Roelofs of New York University was given the Michael Harrington Award, which is awarded yearly to the author of a book which best exemplifies the goals of the Caucus. His book is entitled Poverty of American Politics: $A$ Theoretical Interpretation (Philadelphia: Temple University Press, 1992).

\section{Foundations of Political Theory}

The First Book Award for the first book in political theory was given to Richard C. Sinopoli, University of California at Davis, The Foundations of American Citizenshp: Liberalism, The Constitution and Civic Virtue (New York: Oxford University Press, 1992).

\section{Representation and \\ Electoral Systems}

The George Hallett Prize, presented annually to the author of a book published at least ten years ago that has had a lasting contribution to the literature on representation and electoral systems, was given to Enid Lakeman, How Democracies Vote: $A$ Study of Electoral Systems (London: Faber \& Faber, 1974).

\section{Political Communication}

Elihu Katz, Guttman Institute of Applied Social Research, Jerusalem, Israel, was given the Murray Edelman Distinguished Career Award which is given to a scholar whose lifetime scholarship has advanced the study of political communication in exceptional ways. The citation for Professor Katz's award noted the following: "Two of Professor Katz's early books in particular have had tremendous and long-lasting impacts on the field. His first book, Personal Influence: The Part Played by People in the Flow of Mass Communications, was published in 1956 with Paul Lazarsfeld and has become the landmark study of the role of mass and interpersonal communication in influencing decision-making. A second book entitled Medical Innovation: A Diffusion Study has had a major impact on the field of diffusion research. Professor Katz's publications now span nearly 40 years including his most recent book published in 1992 by Harvard University 
Press entitled, Media Events: The Life Broadcasting of History.

"In addition to the legacy of his extensive research, his enormous contribution to the field of political communication can be seen in the extensive amount of collaborative work he has done with students and colleagues over the years. For the part he has played in all of our lives and work, please join us in congratulating Elihu Katz."

Ann Crigler, University of Southern California, and Timothy E. Cook, Williams College, were given the Ithiel de Sola Pool Award for best paper in political communication from the 1992 APSA meeting.

\section{Political Organizations and Parties}

The Samuel Eldersveld Award for lifetime achievement was given to Joseph Schlesinger, Michigan State University. The Leon Epstein Award for a book that has made a distinguished contribution to the field was given to Maurice Duverger, Les Partis Politiques (Paris: Colin, 1951). The Jack Walker Award for an article of unusual importance and significance to the field was given to Herbert McClosky, Paul Hoffman and Rosemary O'Hara, "Issue Conflict and Consensus among Party Leaders and Followers," American Political Science Review, 1964. The Emerging Scholars Award for significant research by a scholar receiving the doctorate within the past five years was given to Sean J. Savage, St. Mary's College. And the Distinguished Service Award, occasionally presented for unusual contributions to the Section, was given to John C. Green, University of Akron.

\section{Politics and the Life Sciences}

The Association for Politics and the Life Sciences Graduate Student Paper Award was given to Winifred Hodge, University of Illinois at Champaign-Urbana.

\section{Law and Courts}

Henry J. Abraham, University of Virginia, was awarded the Lifetime Achievement Award, which is awarded every three years to honor a career of scholarly distinction in the field of law and courts.

The C. Herman Pritchett Award for best book in the field of law and courts authored by a political scientist in 1991 or 1992 was given to H. W. Perry, Harvard University, Deciding to Decide: Agenda Setting in the United States Supreme Court (Cambridge, MA: Harvard University Press, 1991), and Herbert Kritzer, University of Wisconsin, Let's Make a Deal: Understanding the Negotiation Process in Ordinary Litigation (Madison: University of Wisconsin Press, 1991). The CQ Award for Best Paper in the law and courts field by a political science graduate student who authored or co-authored a paper was given to Julie Novkov, University of Michigan. The American Judicature Society Award for the best papers in the subfield of law and courts presented at the previous year's APSA Annual Meeting was given to Mark Graber, University of Maryland, "The NonMajoritarian Difficulty: Legislative Deference to the Judiciary." Honorable mention went to Elliot E. Slotnick and Jennifer Segal, Ohio State University, "Television News and the Supreme Court."

\section{Public Policy}

The Award for Distinguished Contribution, which recognizes creative policy analysis that has had a significant influence on the course of American public policy, was given to Mollie Orshansky, the woman who developed the poverty measure used government-wide. This year marks the thirtieth anniversary of Ms. Orshansky's path-breaking publication, "Children of the Poor," an article which caught the attention of the Johnson administration and eventually shaped the way both federal statistical agencies and the War on Poverty programs measure poverty. Ms. Orshansky based her poverty estimates on surveys about the food budgets of families as well as studies about the cost of adequate diets.

\section{Urban Politics}

The Career Achievement Award for distinguished contributions to the study of urban politics throughout a career was given to Frederick Wirt, University of Illinois. The Best Book Award for the best book in urban politics published during the calendar year 1992 was given to Richard DeLeon, San Francisco State University, Left Coast City: Progressive Politics in San Francisco, 1975-1991 (Lawrence: University Press of Kansas, 1992).

\section{Committee on the Status of Blacks Honors Scholars}

The Committee on the Status of Blacks in the Profession held a reception in honor of Walter $\mathrm{E}$. Beach, Helen Dwight Reid Educational Foundation, and Hanes Walton, Jr., University of Michigan, in September 3 for their scholarship, service to the profession, and leadership.

The reception was organized by Sheila Ard, committee chair, and Maurice C. Woodard, APSA staff associate.

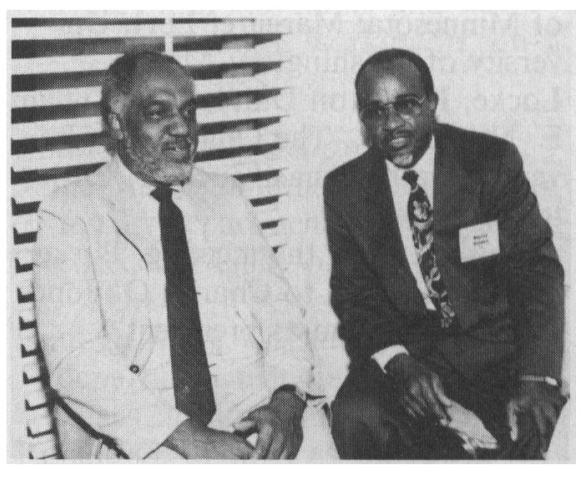

Hanes Walton and Maurice Woodard at Committee on the Status of Blacks Reception. The reception honored Walton and Walter Beach.

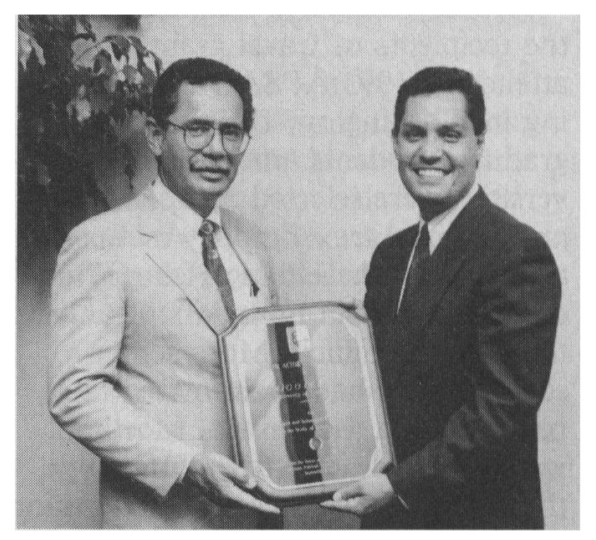

Luis Fraga, chair of the Committee on the Status of Latinos, honors Rodolfo O. Garza on behalf of the Committee. 